\section{Inhibiting Effect of some Antimalarial Substances on Glucose-6-phosphate Dehydrogenase}

COMPOUNDS with antimalarial activity are used as therapeutic agents in a number of disorders other than malarial infections. Our dermatological interest in these substances is two-fold. First, they are specific therapeutics for a number of autoimmune disorders with cutaneous manifestations ${ }^{1}$ and, second, the use of these substances in malarial therapy or prophylaxis often causes adverse cutaneous side effects ${ }^{1}$.

It has been known for some time that individuals with an erythrocytic glucose-6-phosphate dehydrogenase (E.C. 1.1.1.49) deficiency (favism) have an increased resistance to malaria ${ }^{2}$. These individuals also have a high incidence of haemolytic anaemia when given antimalarial drugs prophylactically ${ }^{2}$. These observations suggest that antimalarial drugs inhibit erythrocytic glucose-6-phosphate dehydrogenase (G6PDH) in malaria. Analogously, they may inhibit the G6PDH activity of the reticulo-endothelial system in their capacity as immunosuppressants, and that of the skin in their production of cutaneous manifestations. An essential first test of such an hypothesis is to see if these compounds are capable of such inhibition in vitro. We have therefore tested a range of antimalarial substances on purified yeast G6PDH from Sigma and on whole tissue extracts of erythrocytes and skin.

The usual commercial forms of the antimalarial substances were dissolved and filtered before use. Enzyme was assayed at room temperature by following the formation of NADPH fluorimetrically (exitation $340 \mathrm{~nm}$, fluorescence $460 \mathrm{~nm}$ ), or spectrophotometrically when difficulties from quenching were experienced. The general details of the assay have been described by Halprin and Ohkawara ${ }^{3}$. The reaction mixtures used are given in Table 1.

Table 1 Reaction Mixture for Testing Inhibitors of Glucose-6-phosphate dehydrogenase

\begin{tabular}{|c|c|c|c|c|c|}
\hline & $\begin{array}{c}\text { NADP } \\
0.002 \mathrm{M} \\
\text { in buffer } \\
\text { (ml.) }\end{array}$ & $\begin{array}{c}\text { G6PDH } \\
10^{-3} \mathrm{mg} / \mathrm{ml} . \\
\text { in buffer } \\
\text { (ml.) }\end{array}$ & $\begin{array}{c}\text { Buffer } 0.05 \mathrm{M} \\
\text { Tris }(p \mathrm{H} 7.5) \\
+5 \times 10^{-4} \\
\mathrm{M} \text { EDTA } \\
+0.03 \mathrm{M} \\
\mathrm{MgCl}_{2}(\mathrm{ml} .)\end{array}$ & $\begin{array}{l}\text { Inhibitor } \\
10^{-3} \mathrm{M} \\
\text { in buffer } \\
\text { (ml.) }\end{array}$ & $\begin{array}{c}\text { G6P (diNa) } \\
0.014 \mathrm{M} \\
\text { in buffer } \\
\text { (ml.) }\end{array}$ \\
\hline 1 & 0.10 & 0.10 & 1.60 & 0.10 & 0.10 \\
\hline 2 & 0.10 & 0.10 & 1.69 & 0.10 & 0.10 \\
\hline 3 & 0.10 & 0.10 & 1.69 & 0.10 & 0.01 \\
\hline
\end{tabular}

Before calculating the results it was observed that the inhibition could be reversed completely in most cases by excess NADP, that is, the inhibition was competitive for NADP. Therefore the following equation was used to calculate the $K_{I}$ values

$$
K_{I}=\frac{V_{1}}{V_{0}-V_{1}} \times \frac{K m}{K m+[S]}
$$

where $V_{I}$ is the initial reaction velocity in the presence of the inhibitor, $V_{0}$ the initial velocity of the reaction in the absence of inbibitor, $[I]$ the final concentration of inhibitor, $K m$ the Michaelis-Menton constant, $K_{I}$ the inhibition constant and $[S]$ the concentration of substrate (NADP). This equation was derived by dividing the normal Michaelis-Menton equation by the equation for a competitively inhibited reaction and rearranging to give $K_{I}$.

In normal Lineweaver-Burk plots, the $\mathrm{Km}$ for glucose-6phosphate and NADP were found to be $6.9 \times 10^{-5} \mathrm{M}$ and $1.43 \times 10^{-5} \mathrm{M}$ respectively. The enzyme was specific for NADP, which could not be replaced by NAD, and the reaction was inhibited by NADPH. The results of the inhibition studies are shown in Table 2.
Table 2 Inhibition of G6PDH by Antimalarials

\begin{tabular}{|c|c|c|c|c|c|}
\hline Inhibitor & $\begin{array}{l}\% \text { inhi- } \\
\text { bition at } \\
\text { low } \\
\text { [NADP] }\end{array}$ & $\begin{array}{c}\% \text { inhi- } \\
\text { bition at } \\
\text { low } \\
{[\mathrm{G}-6-\mathrm{P}]}\end{array}$ & $\begin{array}{c}\% \text { inhi- } \\
\text { bition at } \\
\text { high } \\
\text { [NADP] } \\
+ \\
{[\mathrm{G}-6-\mathrm{P}]}\end{array}$ & $\begin{array}{l}\text { Approxi- } \\
\text { mate } K_{I}\end{array}$ & $\begin{array}{l}\text { Method } \\
\text { used }\end{array}$ \\
\hline Paludrine & 30 & - & - & $1.1 \times 10^{-4}$ & Fluorimetric \\
\hline Daraprime & 36.4 & - & $\ldots$ & $8 \times 10^{-5}$ & Fluorimetric \\
\hline Mepacrine & 17.2 & - & - & $1.8 \times 10^{-3}$ & $\begin{array}{c}\text { Spectro- } \\
\text { photo- } \\
\text { metric }\end{array}$ \\
\hline Primaquine & 28.1 & - & - & $1.2 \times 10^{-3}$ & $\begin{array}{c}\text { Spectro- } \\
\text { photo- } \\
\text { metric }\end{array}$ \\
\hline Chloroquine & 47.5 & - & 一 & $5.14 \times 10^{-4}$ & $\begin{array}{l}\text { Spectro- } \\
\text { photo- } \\
\text { metric }\end{array}$ \\
\hline
\end{tabular}

The antimalarial compounds also inhibited the G6PDH reaction in skin and erythrocyte extracts to a similar extent. Gold salts were found to inhibit skin G6PDH noncompetitively and streptomycin to inhibit competitively for glucose-6phosphate. Both of these compounds have a similar therapeutic application and range of side effects as the antimalarials proper $^{1}$.

It is interesting to consider the consequences of such an inhibition to the metabolism of the cell. G6PDH is the rate limiting point of entry into the pentose phosphate shunt which is the sole producer of extramitochondrial NADPH and also produces riboses for nucleic acid synthesis. Obviously inhibition of this enzyme and pathway will have far reaching effects, particularly in subjects such as favists who have a reduced G6PDH activity in the first place. It would also be of great interest to know if subjects who experience lichenoid skin eruptions as a side effect of antimalarial therapy have a skinspecific deficiency in this enzyme. We are currently carrying out such investigations.

We thank Professor J. W. H. Mali, Dr P. D. Mier and Dr R. C. A. Sengers for helpful discussions.

\section{W. K. CotTon}

A. H. M. Sutorius

Department of Dermatology,

Catholic University,

Javastraat 104, Nijmegen

Received April 6, 1971.

1 Rook, A., Wilkinson, D. S., and Ebling, F. J. G., in Textbook of Dermatology, 2, 1209 (Blackwell, Oxford/Edinburgh, 1968).

2 Haiprin, K. M., and Ohkawara, A., J. Invest. Dermatol., 46, 43 (1966).

${ }^{3}$ Harris, H., The Principles of Human Biochemical Genetics (Frontiers of Biology, series 19) (North-Holland, Amsterdam, 1970).

\section{Effect of Infection with Trypanosomes on the Development of Experimental Allergic Neuritis in Rabbits}

DATA obtained from hospitals in western Nigeria ${ }^{1}$ have shown that rheumatoid arthritis is uncommon in that region and, when the disease occurs, it is clinically milder than in Europeans, involving few of the expected immunological changes ${ }^{2.3}$. Other conditions in which auto-immune processes are thought to be involved were also found to be rare, and Greenwood suggested that repeated exposure to parasitic infections might be responsible, at least in part, for the infrequent occurrence of these auto-immune diseases. Infection with the rodent malaria parasite Plasmodium berghei yoelii delayed the onset 